province, and their principal duties are to watch over sanitary conditions in their several jurisdictions; give their attention to the benevolent institutions, and to decide such medicolegal questions as may be submitted to them.

The sanitary corps of doctors has under its charge the care of the ports along the shore, and is composed also of medical men appointed in special cases whenever situations of an urgent character arise and require more constant care and attention than the permanent officials can devote to then. The maritime sanitary defense is governed by the regulations of the sanitary police formed in accordance with the Second International Sanitary Convention, held in Washington, and for its practical working has three sanitary stations created in 1904.

The first of these has been installed in the port of Payta, and gives attention to vessels coming from the north; the second, in the port of Ilo, for all vessels coming from the south, and the third in the port of Callao, the principal seaport of the republic, for those that come directly to it. These sanitary stations have each of them the Clayton apparatus for the disinfection of vessels and cargo. They also have special arrangements ashore for the examination and disinfection of baggage, and also lazarettos, for the observation and isolation of suspicious cases, or in case of epidemics. In the ports of Salaverry, Pacasmayo, Eeten, Mollendo and others, there are also apparatus and means of disinfection for the same purpose.

The Vaccination and Sero-Therapeutic Institute is intended for the preparation and diffusion of the animal vaccine fluirls, and for obtaining the preventive and curative sera for the treatment and prevention of acute infectious and contagious diseases. So far, the work of this institute has been limited to the production of bovine vaccine material, and the prophylactic and curative sera have been imported regularly from Paris. During $1905,5,900$ persons were vaccinated, and of this number the result was satisfactory in 2,693 ; negative in 746 and unknown in 2,461 cases. During 1905 the institute imported from Paris 100 flasks of antipest serum, 100 flasks of antistreptococci serum, 60 flasks of Behring's antidiphtheritic serum, and 30 frosks of antitetanic serum.

THF DIRECTION OF PUBLIC IIEALTh.

The history of the reorganization of this important branch of the government service and many scientific articles on hygiene and sanitation are published in the official Boletin de] Ministerio de Fomento, which appears about every two months, and is used as a channel through which to diffuse a more thorough knowledge of hygiene and sanitation. No. 4 of the second ycar's series contains a classical article on "Yellow Fever" by E. Marchoux and E. L. Simond. No cases of yellow fever have originated on the coast of Peru since the last epidemic in 1868. Compulsory vaccination in the line of coast travel has been instrumental in checking to a large extent one of the scourges of the country-smallpox.

The vigorous fight against the pest by isolation and disinfection, killing of rats and the prophylactic serum treatment have had a signal success in diminishing to a great extent the frequency of this dreadful disease, as I saw only three cases in the Isolation Hospital, and all of these patients were convalescing. Further, proper attention to water supply and sewerage, will in time make typhoid fever a less frequent disease. Those in charge of the direction of public health deserve great credit for what they have already accomplished, and the public may look with confidence to what they will undertake in the future.

\section{THE HYGIENIC INSTITUTE.}

The institution that reflects more credit on the city of Lima than any other is the Hygienic Institute (Fig. 50). It is located opposite the Permanent Exposition building, and is a magnificent two-story edifice devoted exclusively to scientific investigations and research work. It was recently founded and organized by a specialist of repute, the Italian doctor, Ugi Biffi. G. It is divided into two sections, one of chemistry and the other of bacteriology, with a chief at the head of each, and a competent stafi of assistants. Much excellent scientific work has already been done, and we may hopefully look forward to this institute for new discoveries in the untrodden paths of prophylactic and curative serotherapy.

ISOLATION HOSPITAL FOR CONTAGIOUS DISFASES.

The group of admirably built wooden barracks (Fig. 51) on a large sandy lot, near the limits of the city, testifies to the farsightedness of the health authorities of Lima. Two Sisters of Charity and several helpers are in charge of the empty buildings, as only one building is now occupied by the three patients recovering from the bubonic plague (Fig. 52). But the city is ready for any emergency. Every building is ready to be occupied at a moment's notice, and preparedness means everything in sudden outbreaks of contagious diseases. Lima is prepared for emergencies of this kind, and the patients will be comfortably housed the moment they arrive. Everything is in readiness should yellow fever, bubonic plague, smallpox, scarlet fever, measles or any other contagion occur. A large disinfection plant is on the ground and ready for operation at a moment's notice.

Panama, September, 1907.

\section{Clinical Notes}

\section{TWO INSTANCES OF SEVERE NON-FATAL SERUM REACTION.}

\section{A. P. OHLMACHER, M.D. DETROIT.}

The reports by Drs. Wiley ${ }^{1}$ and Boone ${ }^{2}$ of fatal serum accidents, and the discussion aroused thereby, prompt me to record my unpleasant experience, which, fortunately, was less tragic than those mentioned. 'Two cases of sudden reaction following the repeated subcutaneous injection of horse's serum, with very alarming symptons, in two adults undergoing the serum treatment for rheumatism, are the ones in point. As both patients recovered, and since I was cognizant of the phenomenon of serum hypersusceptibility from my work in the serum laboratory, I observed the reactions with special interest, and studied the symptomatic events somewhat more critically than usual. In fact, the contingency of just such an accident had been considered, and I had tried to avert it by administering several "immunizing" injections of the serum during the first eight or ten days of what is shown by animal experimentation to be the sensitizing interval. In both instances the more common "accelerated reaction" of the serum disease, as defined by von Pirquet and Schick, i. e., urticaria, joint pains, and fever, failed to appear. Indeed, it seemed as if these more usual manifestations of serum reaction accumulated and took the form of one severe toxic explosion.

The first patient was the wife of a dentist, under the care of Dr. Carstens, in Harper Hospital, where she expected to be confined in about six weeks. Because of the woman's greatly crippled condition, resulting from a subacute polyarticular rheumatism, the attempt was made to relieve her by treatment with an antistreptococcic serum which had been extolled as efficacious in this affection. The serum was injected subcutaneously in doses of 10 c.c., one each for the first three days, then one at intervals of two or three days. On the fifteenth day after the treatment was commenced, and the occasion of the seventh injection, the accident occurred, there having been up to this time not the slightest evidence of serum reaction, and only a complaint by the patient that she could, within a few minutes after the

1. The Journal, Jan, 11. 1908 , n. 137

2. The Journal, Feb. 8, 1908, p. 453. 
injection, taste the "carbolic acid" (trikresol) with which the serum was preserved.

The injection was performed with the usual technic, the site of that particular one being the interscapular region, with the patient sitting in bed. I had turned to hand the empty syringe to the nurse when the patient exclaimed: "Doctor, what was in that medicine?" "Do you taste the carbolic acid?" I inquired, thinking this the source of complaint. The woman's face wore a very anxious expression as she replied "No," and then with the remarks "I feel so queer! What is the matter? I can not breathe! Oh, Doctor, you have given me the wrong medicine! I am dying!" her previously pallid face became suffused, and she fell backward on the bed, breathless.

At once there appeared a most pronounced congestion of all the exposed cutaneous surfaces, and an enormous general edema by which the head, arms and legs were swollen to much increased size, completely distorting the features and causing to be overwhelmed the previously existing swellings of the affected joints. It seemed that the hands and feet were swollen to twice their size, and with the purplish congestion of the skin the woman's appearance reminded me forcibly of the bloated cadaver of a drowned person. I could feel a feeble, rapid pulse; but no effort at respiration was evident. After an interval that seemed measured by several minutes, but which, of course, was less, a gasping attempt at inspiration occurred, accompanied by a rapid recession of the edema and cyanosis, to give way to a ghastly pallor. After a few ineffectual attempts, spasmodic breathing was resumed, to be followed by moaning, inarticulate efforts at speech, opening of the eyes and gradual return of consciousness.

As soon as the woman could express herself she complained of chilliness, and speedily most severe rigors occurred. These chills, which were not allayed by artificial heat, lasted for about fifteen minutes, and while they were in progress the patient vomited several times. Following the chills the cutaneous surface took on a bright red hue and hyperpyrexia gradually developed, reaching a maximum temperature of $103 \mathrm{~F}$. in about three hours. By the next morning all unpleasant symptoms had subsided, the woman expressed herself as feeling perfectly well, and for a week or two following this incident the rheumatic joints were much more comfortable. $^{3}$ Fears were entertained about the fate of the child in utero, but the subsequent birth of a perfectly normal infant showed that these were groundless.

In the second patient, an adult man reporting to my office for treatment, the cumulative reaction was not so severe as that just described, principally differing in that the apnea was less prolonged and consciousness not entirely lost. Further, a longer interval, perhaps two or three minutes, elapsed before the patient complained of feeling ill. But the same sudden generalized edema and cyanosis manifested themselves, with difficult breathing and a choking sensation, followed by rapid disappearance of the edema and extreme pallor, with chills and romiting, and later by fever. Here, too, a marked relief of the rheumatic symptoms followed the serum reaction. Some ten injections of serum, first at intervals of three days, then two to four days apart, and in doses of 5 c.c. or 10 c.c., had been administered

3. I might parenthetically add my belief that the occasional good results which follow the injection of horse's serum in chronic rheumatism are to be ascribed to the periodic hyperemia and edema, rheumatism are to be ascribed to the periodic hyperemia and edema,
produced in the affected joints as a part of the "accelerated serum reaction." prior to the occasion in question, with no further accelerated reaction than a slight swelling and itching at the injection site, persisting for a dav or two.

\section{SOME NEW STAINING METHODS OF WIDE APPLICABILITY.}

INCLUDING A RAPID DIFFERENTIAL STAIN FOR ELASTIC TISSUE.

F. H. VERHOEFF, A.M., M.D.

Pathologist and Assistant Ophthalmic Surgron, Massachusetts Charitable Eye and Ear Infirmary; Instructor in Ophthalmic Pathology, Harvard University. BOSTON.

Of the numerous staining methods devised for demonstrating elastic tissue, the method of Weigert has given the most satisfactory results. Weigert's solution, however, stains connective tissue diffusely, and thus does not give the sharpest possible differentiation. It has the disadvantages alsa of staining celloidin deeply, of not permitting the use of satisfactory counter stains, and of giving especially unsatisfactory results when used on tissues fixed in Zenker's fluid. The method here to be described is free from these disadvantages, and gives an intense stain of even the finest elastic fibrils. The method gives good results after any of the following fixatives, namely, Zenker's fluid, formaldehyd, formaldehyd followed by Weigert's mordant for myelin sheaths, formaldehyd followed by Marchi's fluid and fairly satisfactory results may be obtained also with tissues decalcified in nitric acid. In the case of fixation in Zenker's fluid, tissues or sections should not be treated with iodin solution before staining. This, moreover, is unnecessary since mercurial precipitates are removed by the staining fluid.

RAPID DIFFERENTIAL ELASTIC TISSUE STAIN.

The staining fluid is made as follows:

Hematoxylin crystals .............. $\mathrm{gm}$.

Absolute alcohol ...............20 c.c.

Dissolve in test-tube by aid of heat, filter, and add in order given :

Aqueous solution (10 per cent.) of ferric

chlorid $\ldots \ldots \ldots \ldots \ldots \ldots \ldots \ldots \ldots \ldots \ldots \ldots \ldots \ldots \ldots$ c.c.

Concentrated Lugol's solution (iodin, 2; potassium iodid, 4; water, 100) .......8 c.c.

This solution may be used. repeatedly and seems to keep indefinitely.

Sections are immersed in the staining fluid for five minutes or longer, and are then differentiated in a 2 per cent. aqueous solution of ferric chlorid. The differentiation requires only a few seconds, and is completed when the connective tissue is observed to take on the color of Lugol's solution. During the process the sections should be kept in motion. In the case of celloidin sections, it is important, of course, to straighten out any edges that are folded over. To observe the stages in the differentiation, the sections may be examined in water under a low magnification. If the differentiation has been carried too far, the sections may be restained, provided that they have not been treated with alcohol.

The sections are now washed in water, followed by 95 per cent. alcohol to remove the stain of the Lugol's solution, and then are allowed to remain in water five minutes or longer. They are then counterstained in a twotenths per cent. solution of water-soluble eosin in 80 per cent. alcohol, passed through alcohol, oil of origanum, and mounted in balsam. 